\title{
EXPERIMENTÁLNE POROVNANIE VPLYVU ORIENTÁCIE OTVOROV NA ODOLNOSŤ PROTI PRETLAČENIU LOKÁLNE PODPRETÝCH STROPNÝCH DOSIEK
}

\author{
EXPERIMENTAL INVESTIGATION OF THE INFLUENCE OF OPENINGS \\ ORIENTATION ON THE PUNCHING RESISTANCE OF FLAT SLABS
}

\author{
L'udmila Kormošová,
}

*1udmila.kormosova@stuba.sk

${ }^{1}$ Slovenská technická univerzita v Bratislave, Stavebná fakulta. Katedra betónových konštrukcií a mostov, Radlinského 11,81005 Bratislava, Slovenská republika

\begin{abstract}
Abstrakt
Príspevok sa zaoberá experimentálnym porovnaním vplyvu orientácie otvorov na šmykovú odolnost’ proti pretlačeniu lokálne podopretých dosiek bez šmykovej výstuže. V rámci experimentov boli odskúšané dva fragmenty lokálne podopretých dosiek oslabených dvoma otvormi. Otvory s rozmermi $240 \mathrm{~mm} \times 150 \mathrm{~mm}$ boli umiestnené symetricky na kratšej strane stenového stĺpa s rozmermi prierezu $950 \mathrm{~mm} \times 150 \mathrm{~mm}$. Experimentálne vzorky sa od seba líšili orientáciou otvorov voči podpere. Okrem porovnania deformácií boli na základe výsledkov vypočítané skutočné dížky kontrolných obvodov skúšaných vzoriek. Porovnaním s teoretickými dížkami kontrolných obvodov podl'a EC2 sa skrátenie kontrolného obvodu pri výrazne obdížnikovom stĺpe javí ako konzervatívne.
\end{abstract}

\section{Kl'účové slova}

Lokálne podopreté dosky, experiment, otvory, pretlačenie, šmyková odolnost'

\begin{abstract}
The article deals with experimental investigation of the influence of openings orientation on the punching resistance of flat slabs. Within the experiments, two isolated fragments of flat slabs were tested. Both specimens were weakened by two symmetrically placed openings with dimensions of $240 \mathrm{~mm} \times 150 \mathrm{~mm}$ adjusted to the shorter side of the elongated column with cross-section of $950 \mathrm{~mm} \times 150 \mathrm{~mm}$. The specimens differed from each other by the orientation of the openings in relation to the support. In addition to the comparison of deformations, the actual control perimeter lengths of the tested specimens were calculated based on the results. Compared to the theoretical lengths of the control perimeters according to EC2, the reduction of the control perimeter appears to be conservative.
\end{abstract}

Key words

Flat slabs, experiment, openings, punching, shear resistance

\section{1 ÚVOD}

Konštrukčné systémy lokálne podopretých stropných dosiek majú v súčasnosti široké uplatnenie vd’aka svojim architektonickým a konštrukčným výhodám. Pri návrhu je najkritickejším aspektom práve uloženie dosky priamo na podperu (stĺp, hlavica, stena). Prenos zat'aženia z dosky do podpery sa uskutočňuje priestorovo usporiadanými šmykovými napätiami a ich koncentrácia môže viest' k zlyhaniu konštrukcie, nazývanému pretlačenie. Pretlačenie má charakter náhleho zlyhania konštrukcie a ktorému nepredchádzajú žiadne výrazné signály, jedná sa o tzv. krehké zlyhanie. Krehké zlyhanie môže viest' až k progresívnemu zlyhaniu celej konštrukcie alebo jej časti. Vel'kost' šmykového napätia, ktoré je príčinou zlyhania dosky zvyšuje aj prítomnost' otvorov v doske. Otvory v doske zmenšujú čast' dosky, ktorá odoláva zlyhaniu a jej šmyková odolnost' proti pretlačeniu klesá. V projekčnej 
praxi sa otvory vo vel'kej miere umiestňujú práve v blízkosti stĺpov. Ide hlavne o šachty, alebo prierazy na vedenie potrubí a iných technických inštalácii. Na šmykovú odolnost’ a rozloženie šmykových napätí v okolí podpery má výrazný vplyv nie len tvar, poloha a vel'kost' otvorov, ale aj tvar podpery. Pri podopretí výrazne obdížnikovým (stenovým stĺpom), kde väčší z rozmerov stípa $(h)$ je viac ako trojnásobok účinnej výšky dosky $d$, sa šmykové napätia sústred'ujú hlavne v rohoch podpery. Súčasné normové postupy sa líšia v spôsobe započítania vplyvu otvorov na šmykovú odolnost' proti pretlačeniu a vychádzajú z databázy výsledkov na fragmentoch dosiek podopretých štvorcovým, príp. kruhovým stĺpom. Na Obr. 1. je znázornený spôsob redukcie základného kontrolného obvodu pre Eurokód 2 (EC2) [1] a pre pripravovanú novú generáciu Eurokódu 2 (EC2v2) [2].
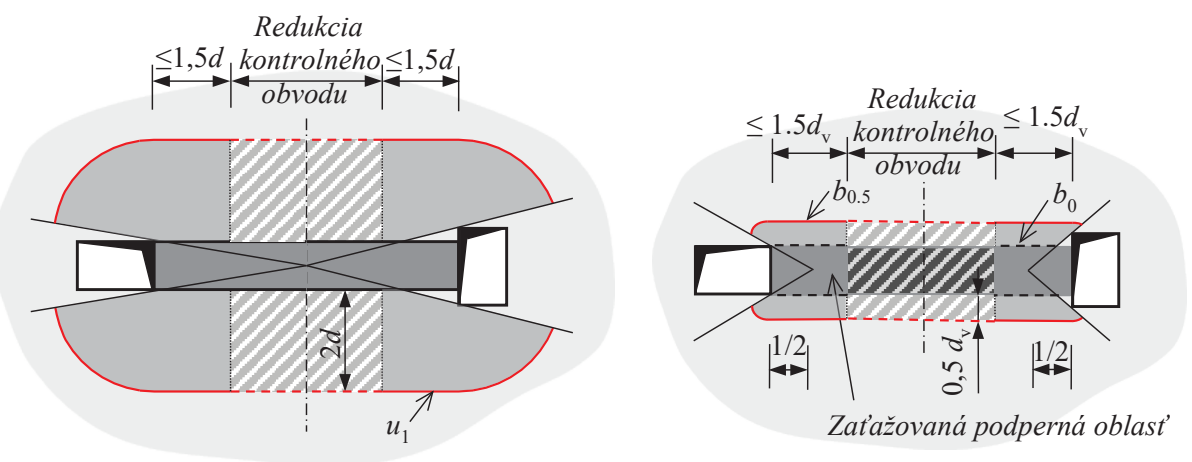

Obr. 1 Redukcia kontrolných obvodov: a) EC2, b) EC2v2.

Experimentálne štúdie zaoberajúce sa súčasne šmykovou odolnost'ou lokálne podopretých dosiek s otvormi a zároveň vplyvom stenového stípa sú vel'mi zriedkavé. V posledných rokoch výskum uskutočnili Teng, Cheong \& Kuang [3], Borges, Melo a Gomez [4] a Oliviera, Gomes Melo [5]. Najrozsiahlejší bol experimentálny program prof. Tenga [1], ktorý obsahoval 20 dosiek s otvormi bez šmykovej výstuže s hrúbkou dosky $150 \mathrm{~mm}$. Počet vyššie uvedených výskumov naznačuje, že vyšetrenie vplyvu otvorov pri výrazne obdížnikových stĺpoch, overenie spol'ahlivosti a ich zohl'adnenia v normových postupoch je stále vel'mi aktuálna téma.

V práci sú porovnané výsledky dosiahnuté na základe experimentov na dvoch izolovaných fragmentoch dosiek so symetricky umiestnenými otvormi na líci kratšej strany výrazne obdĺžnikového stĺpa, pričom sa mení ich orientácia voči podpere. Riešené vzorky sú súčast’ou prebiehajúceho experimentálneho programu na súbore 6 lokálne podopretých dosiek.

\section{OPIS EXPERIMENTU}

Analyzované vzorky predstavujú dosko-stenové izolované fragmenty, ktorých výroba prebiehala v závode Strabag, s. r. o. v Seredi. Spolu so vzorkami bezprievlakových fragmentov dosiek boli vyhotovené betónové kocky, valce a hranoly na určenie materiálových vlastností betónu. Experiment bol vykonaný v Centrálnych laboratóriách SvF STU.
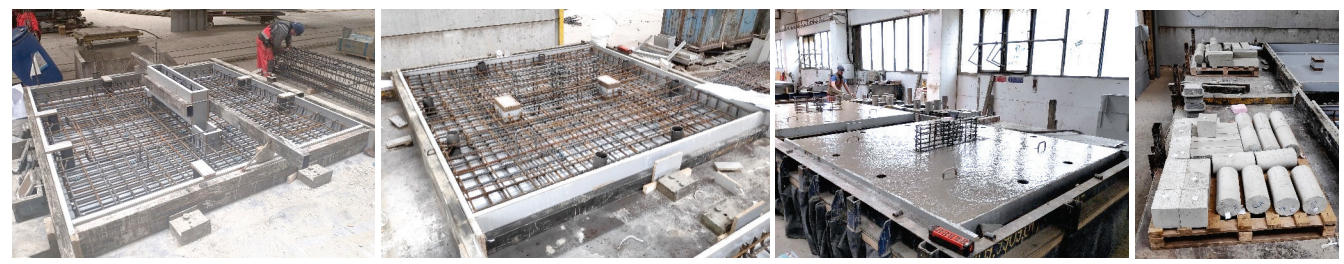

Obr. 2 Výroba vzoriek: pohl'ad do debnenia, vzorka po zabetónovaní, materiálové vzorky. 


\section{Experimentálne vzorky}

Analyzované vzorky sú bez šmykovej výstuže a majú pôdorysný rozmer $2,5 \times 2,5 \mathrm{~m}$ a výškou $h=200 \mathrm{~mm}$. Vzorky podopiera stenový stĺp s rozmermi prierezu $950 \times 150 \mathrm{~mm}$, kde pomer $h / d=6$. Obe riešené vzorky boli oslabené dvojicou otvorov s rozmermi $240 \mathrm{~mm} \times 150 \mathrm{~mm}$. Umiestnenie otvorov v doske bolo navrhnuté symetricky z dôvodu minimalizácie dodatočného vplyvu nevyrovnaných momentov. Geometria vzoriek ako aj orientácia otvorov je zobrazená na Obr. 3. Priemerná pevnost’ betónu v tlaku $f_{\mathrm{c}}$ bola vyhodnotená na 30,36 MPa pre vzorku S označením S1 a 28,43 MPa pre vzorku S2. Stupeň vystuženia bol $\rho=1,2 \%$ (ø16/100 mm pre oba smery). Krytie výstuže bolo $20 \mathrm{~mm}$. Maximálne zrno kameniva v betonárskej zmesi bolo predpísané na $d g_{\text {,max }}=16 \mathrm{~mm}$.
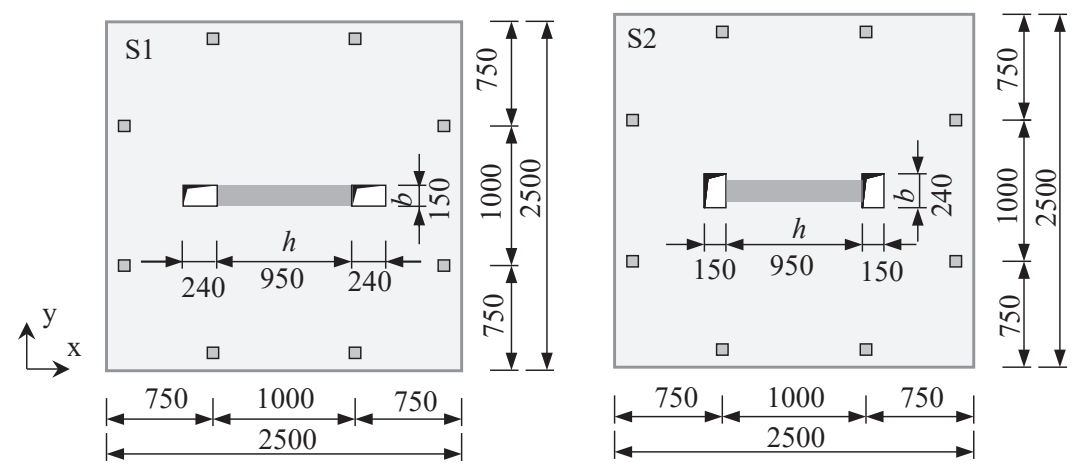

Obr. 3 Schéma geometrie vzoriek S1 vl'avo a S2 vpravo.

\section{Zat'ažovacia zostava}

Experimentálna zostava zobrazená na Obr. 4. bola navrhnutá tak, aby sa zat’aženie vnášalo zhora na dol pomocou 4 hydraulických lisov. Všetky lisy boli umiestnené spolu so silomerom medzi dve dvojice ocel'ových nosníkov. Po vyvinutí sily sa silomer zaprel do hornej dvojice nosníkov, ktorá bola ukotvená do podlahy 2 závitovými tyčami a spodnej dvojice nosníkov, ktorá reakciu preniesla priamo do dosky pomocou ocel'ových kalót, slúžiacich ako kíbová podpera. Dosku podopieral fragment obdížnikového stĺpa uložený na dvojicu ocel’ových nosníkov.

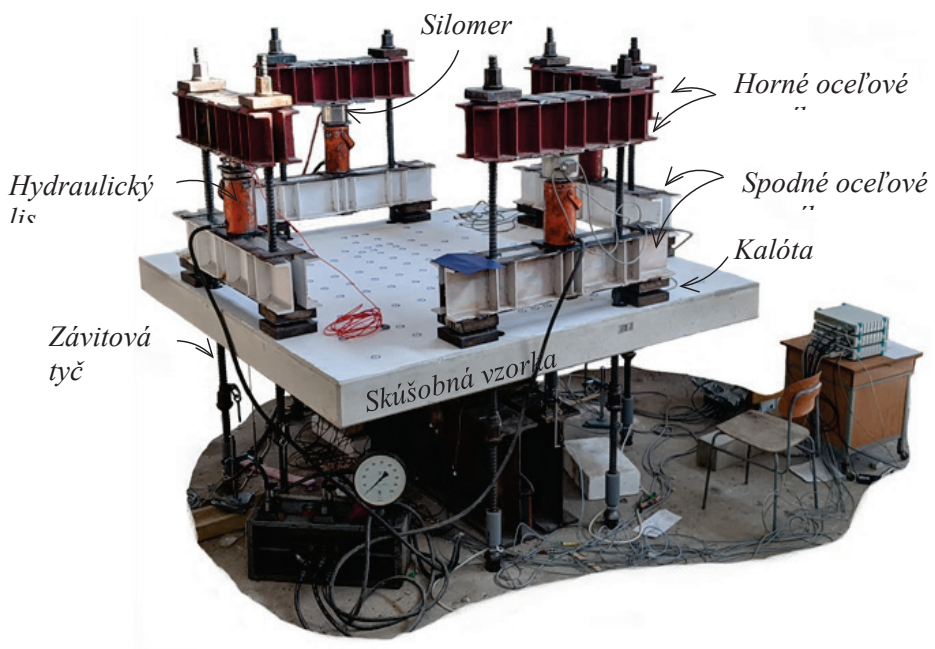

Obr. 4 Experimentálna zostava. 


\section{Priebeh experimentu a zaznamenávanie nameraných veličín}

Zat'ažovanie prebiehalo postupne v zat’ažovacích krokoch. Sily boli zaznamenaná štyrmi silomermi, pričom najprv sa vzorka zat'ažila v prvom kroku na $20 \mathrm{kN}$ a v druhom na $50 \mathrm{kN}$. Ďalej sa postupovalo po krokoch vel'kosti $50 \mathrm{kN}$ a $100 \mathrm{kN}$ a postupne bolo možné pozorovat' vznik a rozvoj trhlín. Na hornom povrchu dosky boli umiestnené geodetické RAD (Riged Automatically Detecterd Coded) značky na zaznamenávanie priestorových premiestnení po každom zat’ažovacom kroku pomocou viacsnímkovej konvergentnej fotogrametrie Obr. 5. a) a Obr. 5. b). Na meranie deformácie dosky sa použili LVDT snímače umiestnené pri spodnom povrchu dosky.

Zat'ažovanie vzorky S1 prebehlo bez problémov a vzorka zlyhala pretlačením pri zat’ažovacom kroku so silou 825 kN. Je nutné spomenút', že výsledné hodnoty deformácií získaných pomocou fotogrametrie pri zat’ažovacom kroku $825 \mathrm{kN}$ nie sú tak presné, nakol'ko doska zlyhala priamo počas zaznamenávania snímok potrebných na vyhodnotenie. Výsledná hodnota odolnosti $856 \mathrm{kN}$ bola získaná pripočítaním vlastnej tiaže dosky.

Počas zat’ažovania vzorky S2 bolo pozorované natočenie zostavy. Skúška bola prerušená aby sa zostava vyrovnala a poloha sa zabezpečila ret’azami vid'. Obr. 5. c). Vd’aka tejto skúsenosti boli počas zvyšných skúšok v rámci experimentálneho programu použité stužujúce ocel'ové prvky. Vzorka S2 zlyhala pri zat’ažovacom kroku 750 kN, skôr než bolo možné v tomto kroku zaznamenat' premiestnenia pomocou fotogrametrie. Výsledná hodnota odolnosti $781 \mathrm{kN}$ bola získaná pripočítaním vlastnej tiaže dosky.
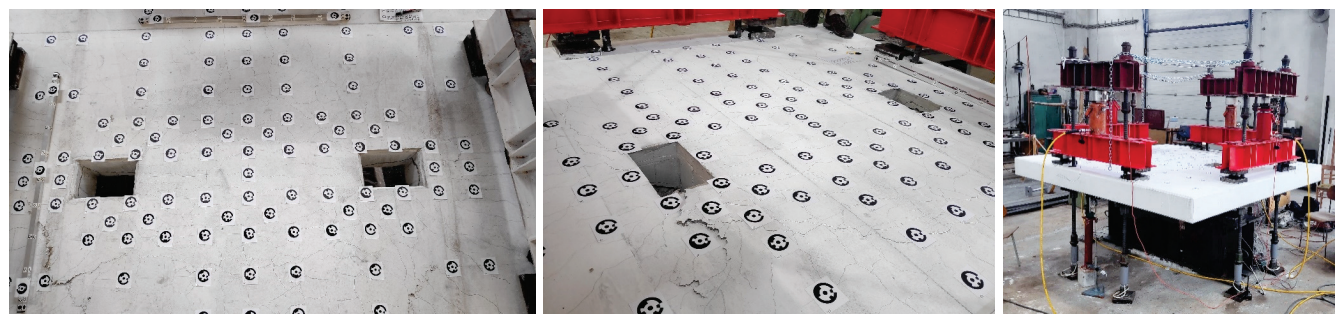

Obr. 5 Priebeh a meranie experimentu: a) porušenie vzorky $\mathrm{S} 1$, b) porušenie vzorky $\mathrm{S} 2$,

c) vzorka S2 - zabezpečenie zostavy.

$\mathrm{V}$ práci je porovnávaný zvislý priehyb $\mathrm{v}$ osiach $x$ a $y$ meraný pomocou fotogrametrie $\mathrm{v}$ jednotlivých zat’ažovacích krokoch. Porovnané sú tiež výsledky deformácie nameraných v monitorovacích bodoch $M x_{1}$ a $M y_{1}$ pomocou fotogrametrie a deformácie v bodoch $M x_{2}, M y_{2}$ zaznamenaných LVDT snímačmi pri spodnom povrchu dosky. Orientácia súradnicového systému a poloha monitorovacích bodov je znázornená na Obr. 6 .

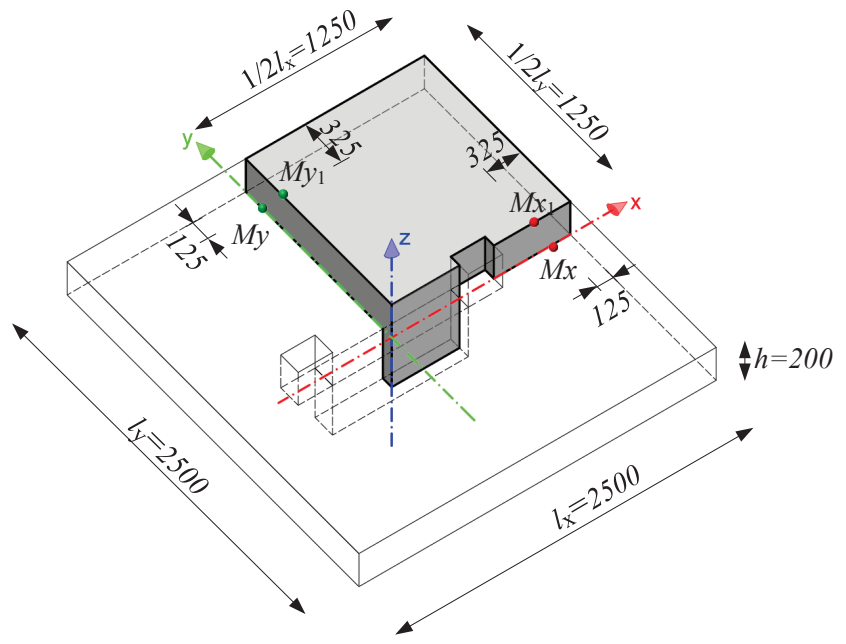

Obr. 6 Orientácia súradnicového systému a poloha monitorovacích bodov použitých pri vyhodnocovaní. 


\section{VYHODNOTENIE}

Výsledné hodnoty šmykovej odolnosti v pretlačení získané z výsledkov experimentov sú zhrnuté v Tab. 2. Z výsledkov je možné pozorovat', že vzorka S2 má menšiu šmykovú odolnost' pri pretlačení, čo je spôsobené zmenšením dížky základného kontrolného obvodu v porovnaní so vzorkou S1. Túto skutočnost' zahŕňajú všetky v súčasnosti používané normové postupy. Zo získaných výsledkov boli vypočítané skutočné dížky kontrolného obvodu v súlade so súčasne platnou normou EC2 vid'. Tab. 1. a následne boli porovnané s teoretickou dížkou kontrolných obvodov na základe redukcie podl'a EC2 vid’. Obr. Chyba! Záložka není definována. a). Porovnaním skutočnej dĺžky kontrolného obvodu $u_{\exp }$ a teoretickej dĺžky $u_{1}$ sa ukazuje normou stanovená redukcia ako vel'mi konzervatívna pre obe vzorky rovnako s pomerom $u_{\mathrm{exp}} / u_{1}=1,52$ resp. 1,51 . Ak sa pri výpočte neuvažovala redukcia $\mathrm{v}$ dôsledku stenovej podpery rozdiel medzi $u_{\mathrm{exp}} / u_{1}{ }^{*}=1,14$ pre dosku S1 a 1,11 pre dosku S2. Skúšané vzorky neboli po skúške rozrezané, preto vo vyhodnotení nie sú uvedené skutočné sklony tlakovej diagonály a skutočný obvod porušenia. Po zlyhaní bolo možné vidiet' tvar šmykového obvodu porušenia, ale skutočná hodnota by sa dala odčítat' až po odbití krycej vrstvy.

Tab. 2 Výsledky hodnôt z experimentov $V_{\text {Rc,exp. }}$

\begin{tabular}{ccccccc}
\hline & $\begin{array}{c}\text { Podpera }(\boldsymbol{x} \times \boldsymbol{y}) \\
{[\mathbf{m m}]}\end{array}$ & $\begin{array}{c}\text { Otvor }(\boldsymbol{x} \times \boldsymbol{y}) \\
{[\mathbf{m m}]}\end{array}$ & $\begin{array}{c}\boldsymbol{d} \\
{[\mathbf{m m}]}\end{array}$ & $\begin{array}{c}\boldsymbol{\rho} \\
{[\mathbf{\%}]}\end{array}$ & $\begin{array}{c}\boldsymbol{f}_{\mathrm{c}} \\
{[\mathbf{M P a}]}\end{array}$ & $\begin{array}{c}\boldsymbol{V}_{\exp } \\
{[\mathbf{k N}]}\end{array}$ \\
\hline S1 & $950 \times 150$ & $240 \times 150$ & 164 & 1,22 & 30,36 & 856 \\
S2 & $950 \times 150$ & $150 \times 240$ & 164 & 1,22 & 28,43 & 781 \\
\hline
\end{tabular}

Tab. 3 Porovnanie kontrolného obvodu $u_{1}$ podl’a EC2 a $u_{\text {exp }}$ získaného na základe výsledkov experimentov

\begin{tabular}{cccccc}
\hline & $\begin{array}{c}\boldsymbol{u} \mathbf{1} \\
{[\mathbf{m m}]}\end{array}$ & $\boldsymbol{u}{ }^{*}$ & $\boldsymbol{u}_{\exp }$ & $\boldsymbol{u}_{\exp } / \boldsymbol{u}_{\mathbf{1}}$ & $\boldsymbol{u}_{\mathbf{e x p}} / \boldsymbol{u}_{\mathbf{1}}{ }^{*}$ \\
{$[\mathbf{m m}]$} & {$[-]$} & {$[-]$} & 1,14 \\
\hline S1 & 2715 & 3631 & 4126 & 1,52 & 1,11 \\
S2 & 2555 & 3471 & 3847 & 1,51 & \\
* bez redukcie z dôvodu stenového stípa & & & \\
\hline
\end{tabular}

Výsledky deformácii oboch vzoriek získaných z výsledkov nameraných fotogrametriou sú zobrazené na Obr. 7. a Obr. 8. Osový systém je v súlade s Obr. 6. Výsledná zvislá deformácia oboch vzoriek je väčšia v smere menšej tuhosti podpery (smer y).
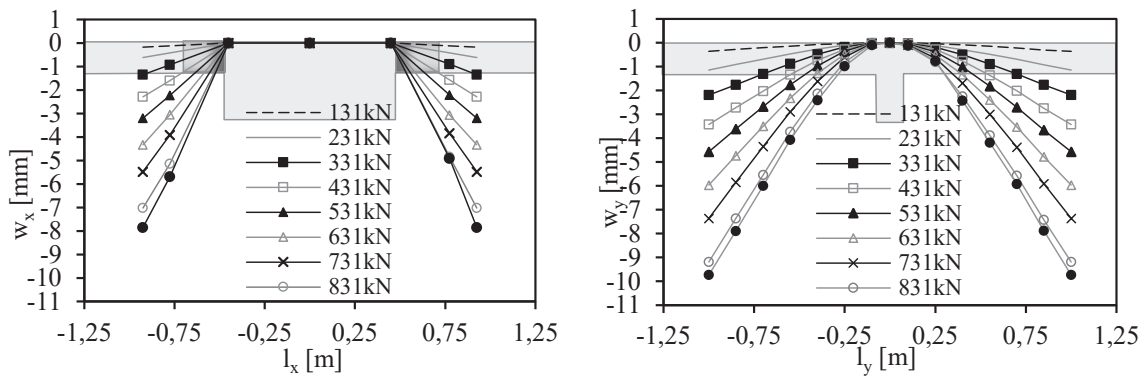

Obr. 7 Deformácia dosky S1: a) v smere $x$, b) v smere $y$.
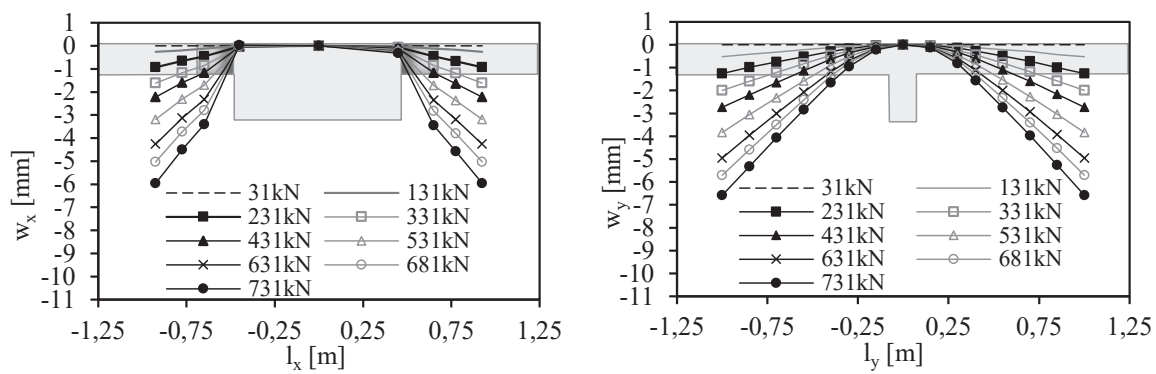

Obr. 8 Deformácia dosky S2: a) v smere $x$, b) v smere $y$. 
Na grafoch (Obr. 9. ) zobrazujúcich normalizovanú zvislú deformáciu v monitorovacích bodoch je vidiet' dobrú zhodu použitých meracích zariadení a zároveň vel'kú podobnost' v postupnej zvislej deformácii v oboch riešených vzorkách. Výsledná šmyková odolnost' sa normalizovala len podielom $V_{\exp } / f_{\mathrm{c}}^{1 / 3}$. Výsledky sa nenormalizovali s prihliadnutím na rôznu dížku kontrolného obvodu. Grafy na Obr. 9. dokazujú, že pri zmene orientácie otvoru s malým pomerom strán nemá skrátenie kontrolného obvodu vplyv na priebeh deformácie.
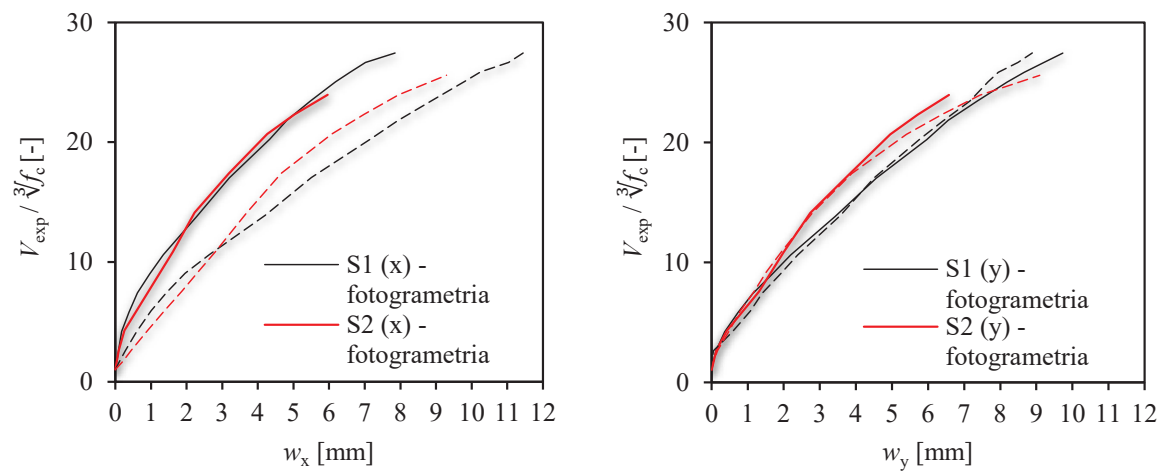

Obr. 9 Porovnanie normalizovaného priehybu nameraného pomocou fotogrametrie a LVDT snímačov v monitorovacích bodoch: a) v smere $x$, b) v smere $y$.

\section{ZÁVER}

Práca sa zaoberá porovnaním výsledkov šmykovej odolnosti proti pretlačeniu experimentálne odskúšaných fragmentov lokálne podopretých dosiek oslabených dvojicou symetricky umiestnených otvorov na kratšej strane stenového stĺpa s prierezom s rozmermi $950 \mathrm{~mm} \times 150 \mathrm{~mm}$. Vzorky neobsahovali šmykovú výstuž. Na základe porovnaní experimentálnych skúšok sa dospelo k nasledujúcim záverom:

- Experimentálne navrhnutá zostava a jej funkčnost’ bola vhodne navrhnutá, nakol'ko skúšané vzorky zlyhali pretlačením pri hodnote blízkej predpokladanej sile.

- Nepreukázala sa potreba redukcie dížky kontrolného obvodu v dôsledku výrazne obdížnikového tvaru podpery, kde $c_{\max }>3 d$ podl'a súčasne platného výpočtového postupu EC2.

- Orientácia otvoru daných rozmerov umiestneného na kratšej strane stenovej podpery má vplyv na šmykovú odolnost' dosiek ale nemá výrazný vplyv na priebeh deformácie dosky.

\section{Pod'akovanie}

Táto práca vznikla s podporou výskumného projektu VEGA č. VEGA 1/0254/19 "Šmyková odolnost' železobetónových dosiek namáhaných koncentrovaným zat’ažením".

\section{Použité zdroje}

[1] EN 1992-1-1: Eurocode 2 - Design of Concrete Structures, Part 1-1 General Rules and Rules for Buildings, CEN/CENELEC, TC250, 2004.

[2] CEN/TC250/SC2/N 1874 Eurocode 2: Design of Concrete Structures (2021) - Part 1-1: General rules for buildings, bridges and civil engineering structures, latest draft prEN 1992-1-1:2021-01.

[3] TENG, S. et al.: Punching shear strength of slabs with openings and supported on rectangular columns, ACI Structural Journal, V. 101, No. 5, 2004. s. 678-687.

[4] BORGES, L. L. J. et al.: Punching shear of reinforced concrete flat and plates with openings, ACI Structural Journal, Vol. 110, No. 4, 2013. s. 547-556.

[5] OLIVEIRA, D. C. et al.: Punching shear in reinforced concrete flat slabs with hole adjacent to the column and moment transfer. In Revista IBRACON de Estruturas, 2014. 